\title{
Regulation of the vascular endothelial growth factor and growth by estrogen and antiestrogens through Efp in Ishikawa endometrial carcinoma cells
}

\author{
HONGYING DAI ${ }^{1,3}$, PING ZHANG ${ }^{2}$, SHUPING ZHAO ${ }^{3}$, JINGJING ZHANG $^{3}$ and BO WANG ${ }^{1}$ \\ ${ }^{1}$ Department of Obstetrics and Gynecology, Qilu Hospital, Shandong University, Jinan; ${ }^{2}$ Department of \\ Obstetrics and Gynecology, Qingdao Municipal Hospital, Qingdao; ${ }^{3}$ Department of Obstetrics and \\ Gynecology, Affiliated Hospital of Qingdao Medical College, Qingdao University, Qingdao, P.R. China
}

Received February 5, 2008; Accepted March 12, 2008

DOI: 10.3892/or_00000235

\begin{abstract}
Vascular endothelial growth factor (VEGF) is a potent angiogenic and prognostic factor for endometrial cancer. Estrogen and tamoxifen are considered to be associated with increasing risk of endometrial adenocarcinoma. To investigate the effects and mechanisms of estrogen and antiestrogens (tamoxifen and raloxifene) on the growth of endometrial carcinoma cells in vitro, we performed growth studies of estradiol and antiestrogens on estrogen receptor positive Ishikawa cells. The effects of estradiol and antiestrogens on the induction of VEGF and estrogen-responsive finger protein (Efp) were measured by QRT-PCR and ELISA or Western blotting. The siRNA method was used to investigate the action of Efp on Ishikawa cell growth and the induction of VEGF by estradiol and antiestrogens. Estradiol and tamoxifen induced Ishikawa cell proliferation and expression of Efp and VEGF on mRNA and protein levels, while raloxifene did not. The effects of estradiol were partly or almost completely inhibited by tamoxifen and raloxifene. When the Efp expression was suppressed by siRNA, the cell growth was decreased with estradiol treatment, and other actions of estradiol and tamoxifen such as induction of VEGF were decreased. These results demonstrate that estradiol and tamoxifen may regulate the growth of endometrial carcinoma cells by stimulating VEGF production through Efp, and the effects of estradiol could be amplified by Efp. This study suggest that tamoxifen
\end{abstract}

Correspondence to: Professor Bo Wang, Department of Obstetrics and Gynecology, Qilu Hospital, Shandong University, Jinan, Shandong province 250014, P.R. China

E-mail:wangbojn@yahoo.cn

Key words: endometrial adenocarcinoma, Ishikawa cells, vascular endothelial growth factor, estradiol, tamoxifen, raloxifene acts as an agonist-antagonist, and raloxifene acts as an antagonist of estrogen in Ishikawa cells in vitro.

\section{Introduction}

Endometrial carcinoma is one of the most common gynecological malignancies and its incidence has recently increased. Endometrial adenocarcinoma accounts for $\sim 80 \%$ of endometrial tumors. A causal link between endometrial adenocarcinoma and estrogen or tamoxifen is widely accepted $(1,2)$. Tamoxifen, the first clinically useful selective estrogen receptor modulator (SERM), has antiestrogenic effects in breast tissue and is used to treat or prevent breast cancers. SERMs also have estrogen-like activity in bone and can be used to treat and prevent osteoporosis. Raloxifene is the first SERM used to treat or prevent osteoporosis in postmenopausal women. However, tamoxifen therapy results in increased endometrial hyperplasia and long-term tamoxifen treatment increases the incidence of endometrial carcinoma by three to four-fold in postmenopausal women compared to placebo (2). In contrast, raloxifene has not been shown to increase the incidence of endometrial carcinoma (3).

Estrogen acts by binding to estrogen receptor (ER) $\alpha$ or $\beta$, the ER $\alpha$ predominate in breast and uterus, whereas the ERß, predominate in bone and blood vessels. Tamoxifen and raloxifene compete with estrogen for binding with high affinity to the ERs (4). Efp is one of downstream genes of $\mathrm{ER} \alpha$, it is predominantly expressed in estrogen target tissues including mammary glands, uteri, and osteoblasts $(5,6)$. Efp is essential for growth of female organs such as uteri, since mice deficient in Efp gene have underdeveloped uteri (7).

VEGF is a vasoactive factor that alter the growth behavior of various tissues and have a role in angiogenesis $(8,9)$, it might be involved in the promotion of angiogenesis in endometrial cancer, and might contribute to the aggressive potential of high grade tumors or certain histological subtypes with unfavorable prognosis through the induction of angiogenesis (10). It may be modulated by estrogen $(11,12)$. Some molecular mechanism have been proposed to explain this phenomenon, however, the certain mechanism is still unclear. 
In the present study, we investigated the effects of estradiol on the Ishikawa cell growth and Efp dependent synthesis of VEGF. Furthermore the effects of various antiestrogens, i.e. tamoxifen, raloxifene, alone and in combination with estradiol were investigated. We also investigated the Efp gene function by means of siRNA to analyze the effect of the Efp on Ishikawa cells in vitro.

\section{Materials and methods}

Reagents. Cell culture medium DMEM-high glucose medium without phenol red, estradiol(E2) and 4-hydroxytamoxifen (4OHT) were purchased from Sigma (St. Louis, MO). They were solubilized in ethanol and added to the culture medium to obtain a final of concentration of ethanol $<0.1 \%$. Antibodies against Efp and secondary antibody were obtained from Santa Cruz Biotechnology (Santa Cruz, CA). ShRNAs were synthesized by Jingsai (Wuhan, P.R. China).

Cell culture. Ishikawa human endometrial carcinoma cells were purchased from Maisha (Shanghai, P.R. China). They were established in 1985 by Nishida et al from an endometrial adenocarcinoma that was ER and PR positive (13). In our study, the cells were routinely cultured in DMEM-high glucose medium without phenol red supplemented with $10 \%$ fetal bovine serum at $37^{\circ} \mathrm{C}$ in a humidified atmosphere of $5 \% \mathrm{CO}_{2}$.

Efp siRNA transfection. Transfection was done using Lipofectamine 2000 (Invitrogen) according to the manufacturer's instructions. Six hours after transfection, the medium was replaced with fresh medium. The transfected cells were collected at different intervals after transfection and analyzed by quantitative real-time PCR (QRT-PCR) and Western blotting. Mock siRNA was used as a control. The targeted sequence of Efp shRNAs were as follows: 1) 5'-GAA CACGGUGCUGUGCAACCUUGCACGCACCGUGUU CUU-3'; 2) 5'-CUGUGACCACGGCUUUGUCCACAA AGCCGUGGUCACAGUU-3'; 3) 5'-GGUCCACCUGAU GUAUAAGCUUAUACAUCAGGUGGAC- 3 '. At first, we checked all the three shRNAs individually. Of the three shRNAs tested, shRNA no. 3 showed substantial and consistent reduction in the Efp levels, therefore this shRNA was used in the study.

Growth experiments. All growth experiments were performed in phenol-red-free medium to remove endogenous steroids containing $10 \%$ fetal bovine serum. One day prior to induction, cells were trypsinized and seeded in equal number into 24-well plates. The cells were induced next day with indicated concentration of E2, 4OHT, raloxifene (Eli Lilly, USA) and ethanol (control). Cells were trypsinized from these wells on alternate days for six or eight days, and counted with a hemocytometer. Medium containing different compounds was also replaced on alternate days.

RNA extraction and cDNA synthesis. Total RNA was isolated from cell lines using TRIzol reagent (Invitrogen) according to the manufacturer's instructions and stored at $-70^{\circ} \mathrm{C}$ until use. Total RNA was reverse transcribed into cDNA using
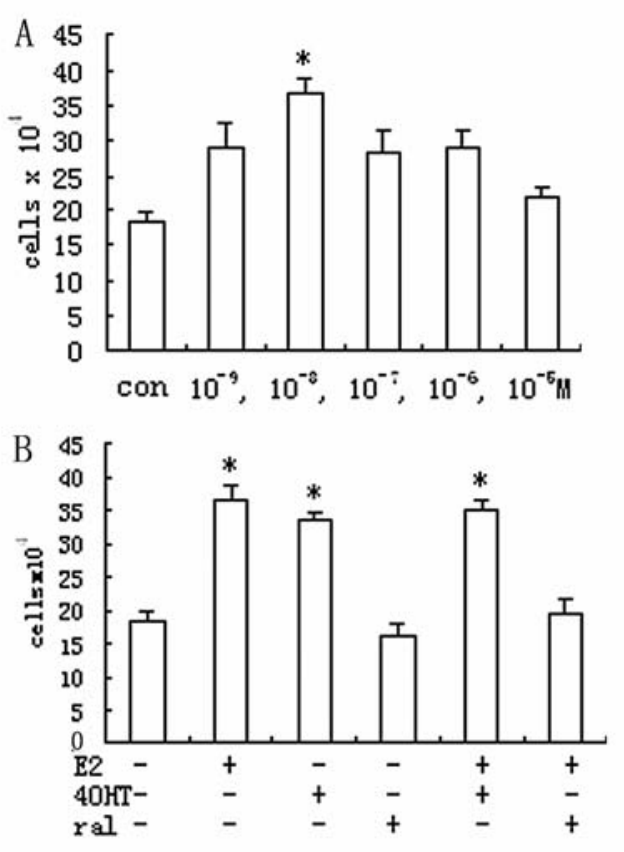

Figure 1. Effect of E2 and antiestrogens on Ishikawa cell growth. (A) Dosedepended effect of E2 on Ishikawa cell growth at day 8. (B) Effect of E2 and antiestrogens on Ishikawa cell growth. Each bar represents the mean number of three wells \pm SE obtained from three separate experiments. The asterisk indicates significant difference compared with the control $\left({ }^{*} \mathrm{P}<0.05\right)$.

the reverse transcription reagents (Takara, Dalian, P.R. China) in a final volume of $10 \mu \mathrm{l}$ containing PrimeScript ${ }^{\mathrm{TM}}$ buffer $2 \mu \mathrm{l}$, PrimeScript RT enzyme mix I $0.5 \mu 1,25 \mathrm{pmol}$ of Oligo dT Primer, 50 pmol of random 6 mers and $500 \mathrm{ng}$ of total RNA. The samples were incubated at $37^{\circ} \mathrm{C}$ for $15 \mathrm{~min}$, and reverse transcriptase was inactivated by heating at $85^{\circ} \mathrm{C}$ for $5 \mathrm{sec}$. Samples were preserved at $-20^{\circ} \mathrm{C}$ until use.

QRT-PCR. Primers and probes for Efp, VEGF and glyceraldehyde-3-phosphate dehydrogenase (GAPDH) were designed with Primer Express 1.5 software (Applied Biosystems), and synthesized by Takara. The sequences for all primers and probes were Efp, forward, 5'-CGAGGT GGAACTGAACCACAA-3'; reverse, 5'-TTCACAGGG CGTGTGGATTT-3'; probe, 5'-FAM-AAACGAGCTGAA GCAGTGCATCGGG-TAMRA-3'; VEGF, forward, 5'-AAG ATCCGCAGACGTGTAAATGTT-3; reverse, 5'-CGGCTT GTCACATCTGCAAGTA-3'; probe, 5'-FAM-TTGCAA GGCGAGGCAGCTTGAGTTATAMRA-3'; GAPDH, forward, 5'-GAAGGTGAAGGTCGGAGTCA-3'; reverse, 5'-GAAGATGGTGATGGGATTTC-3'; probe, 5'-FAM-CAA GCTTCCCGTTCTCAGCC-TAMRA-3'. All probes were labeled with FAM as reporter and with TAMRA as quencher. The PCR kit (Takara) was used for the PCR reaction. In a total volume of $20 \mu 1,2 \mu 1$ of the cDNA, $160 \mathrm{nM}$ probe and $200 \mathrm{nM}$ primer were used. PCRs were performed with the ABI Prism 7500 sequence detection system (Applied Biosystems). The PCR conditions were $95^{\circ} \mathrm{C}$ for $10 \mathrm{sec}$, followed by 40 cycles of $95^{\circ} \mathrm{C}$ for $5 \mathrm{sec}$ and $60^{\circ} \mathrm{C}$ for $34 \mathrm{sec}$. Human GAPDH was used as an internal control, and each total RNA sample was normalized to the content of GAPDH mRNA using the comparative $\Delta \Delta \mathrm{C}_{\mathrm{T}}$ method. 


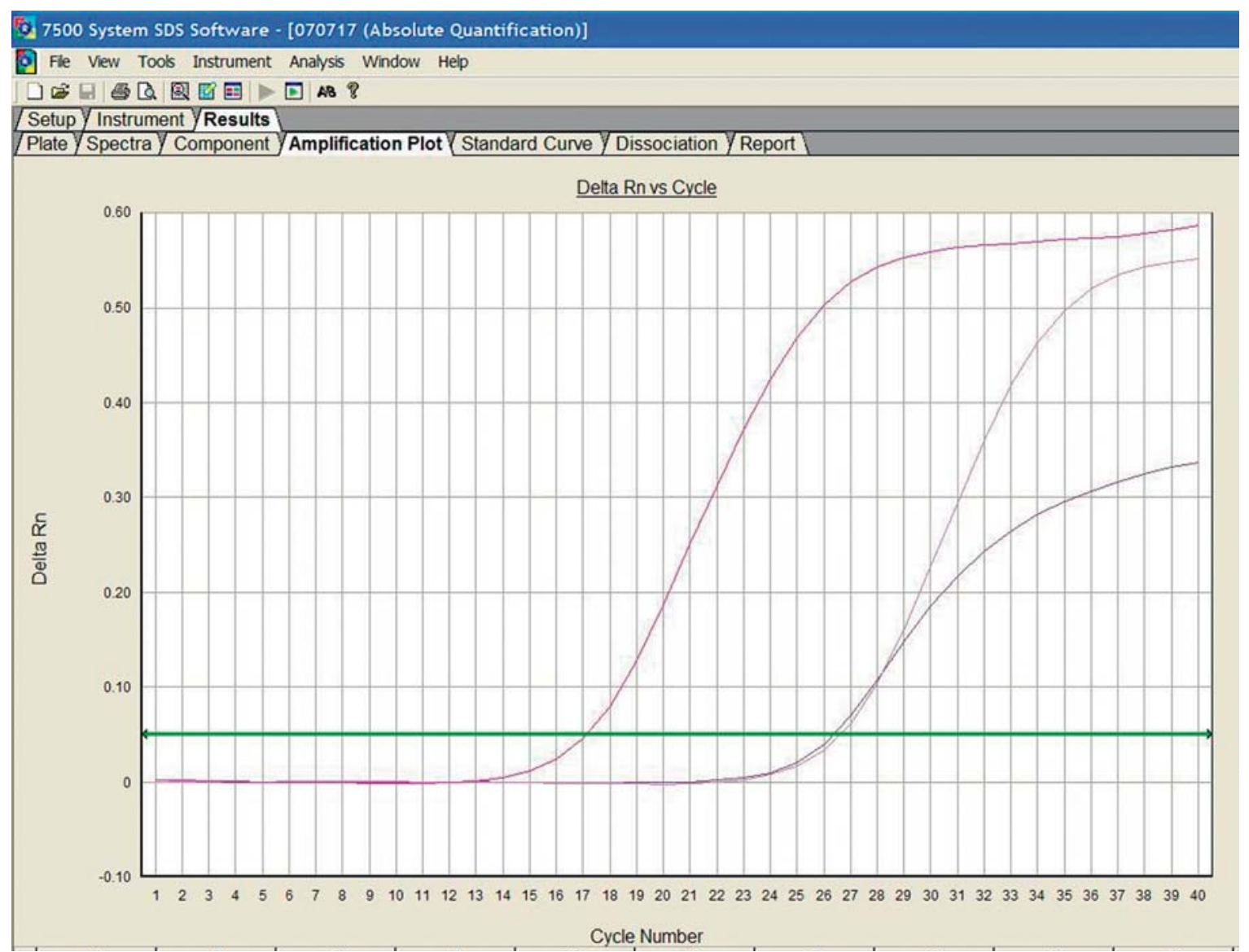

Figure 2. Efp and VEGF mRNA expression in Ishikawa cells. Kinetics of QRT-PCR for Efp and VEGF mRNA in Ishikawa cell line. The three curves represent the mRNA expression of VEGF, Efp and GAPDH.

Western blot analysis. Collected cells were homogenized and then lysed in $0.2 \mathrm{ml}$ of a cell lysis buffer ( $0.1 \%$ SDS, $1 \%$ NP-40, 1\% glycerin, $50 \mathrm{mM}$ Tris, $\mathrm{pH}$ 7.4, 2 mM EDTA, and $100 \mathrm{mM} \mathrm{NaCl}$ ). Next, $30 \mu \mathrm{g}$ of total protein was separated by $10 \%$ SDS-polyacrylamide gel electrophoresis and transferred onto a polyvinylidene difluoride membrane. Membranes were subsequently blocked for $1 \mathrm{~h}$ at room temperature in $5 \%$ non-fat milk in PBS, incubated with anti-Efp antibody at a dilution of $1: 400$ overnight at $4{ }^{\circ} \mathrm{C}$, then rinsed and incubated for $1 \mathrm{~h}$ with horseradish-peroxidase-conjugated secondary antibody at a dilution of 1:2000. Enhanced chemiluminescence was carried out using enhanced chemiluminescence kit (Amersham, Buckinghamshire, UK). Efp was readily detectable at approximately $68 \mathrm{kDa}$. The reactions were analyzed by FluorChem IS-9900 Imaging System, and band intensities were quantified using AlphaEaseFC Imaging software 4.0 (Alpha Innotech Corp., San Leandro, CA). An internal reference sample (same on each blot) was included as the standard for quantification. The standard was set to $100 \%$. The signal from each band was correlated to the standard, and this relative number was used for statistical analysis.

VEGF measurement. Cells were seeded at a density of $6 \times 10^{4}$ per well in 24 -well plates in $500 \mu 1$ medium. Next day cells were treated with E2 $\left(10^{-8} \mathrm{M}\right), 40 \mathrm{HT}\left(10^{-7} \mathrm{M}\right)$, raloxifene $\left(10^{-7} \mathrm{M}\right)$ and ethanol (control). The medium was collected at various time intervals and centrifuged at $12,000 \mathrm{rpm}$ for $10 \mathrm{~min}$ at $4^{\circ} \mathrm{C}$ then the supernatant were stored at $-70^{\circ} \mathrm{C}$ for later use. VEGF levels in cell culture media were measured using an ELISA kit (R\&D system) according to the manufacturer's instructions.

Statistical analysis. Statistical significance was evaluated by analysis with t-test, values of $\mathrm{P}<0.05$ were accepted as significant. Each experiment was repeated 3 times to verify the reproducibility of the results. All experiments are shown as mean of triplicate \pm standard error (SE).

\section{Results}

Effect of E2 and antiestrogens on Ishikawa cell growth. The dose dependence study showed that the maximum response in growth rate induction was obtained by using $10^{-8} \mathrm{M} \mathrm{E} 2$ (Fig. 1A). Therefore, the following experiments used this concentration. E2 and 4OHT, but not raloxifene, induced Ishikawa cell proliferation. When $4 \mathrm{OHT}$ and raloxifene were combined with E2, the effect of stimulation by E2 was partly or almost completely reduced (Fig. 1B).

Efp and VEGF mRNA expression in Ishikawa cells. In order to assess expression of Efp and VEGF mRNA in Ishikawa cell lines, we performed QRT-PCR experiments as described in Materials and methods (Fig. 2). 

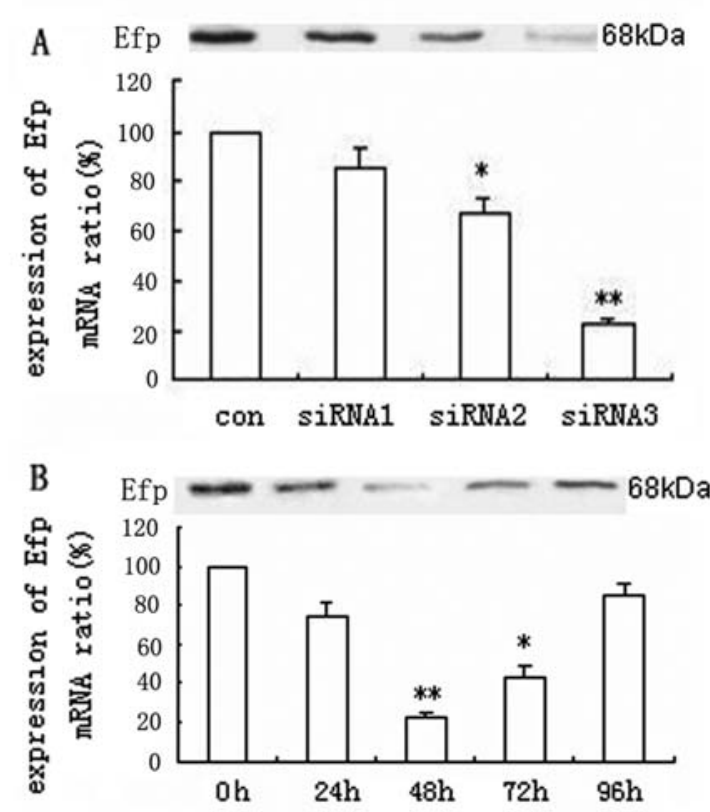

Figure 3. Efp siRNA transfection. (A) Success of RNA interference was analyzed with shRNA no. 3. (B) Effect of RNA interference at different time with shRNA no. 3. The asterisk indicates significant difference compared with the control $\left({ }^{* *} \mathrm{P}<0.001,{ }^{*} \mathrm{P}<0.05\right)$.

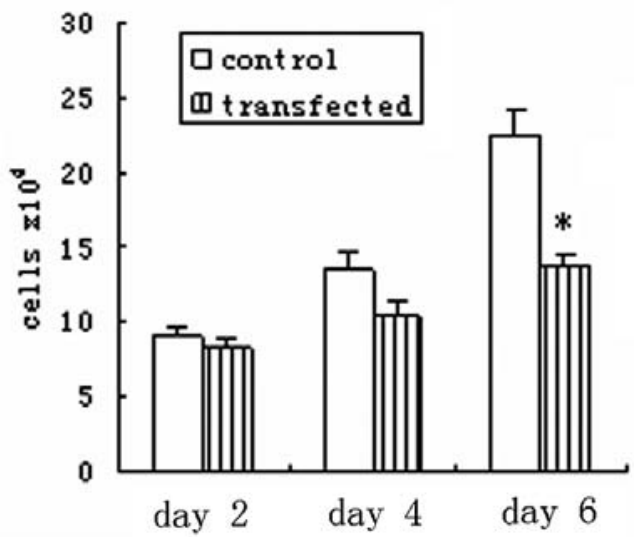

Figure 4. Effect of E2 on Ishikawa cell growth after Efp siRNA. Each bar represents the mean number of three wells \pm SE obtained from three separate experiments. The asterisk indicates significant difference compared with the control $\left({ }^{*} \mathrm{P}<0.05\right)$.

Efp siRNA transfection. Success of RNA interference was analyzed with shRNA no. 3 after $48 \mathrm{~h}$ of transfection (Fig. 3A). The shRNA no. 3 was able to reduce Efp mRNA levels to $21.8 \%$ of the mock transfected control after $48 \mathrm{~h}$, a reduction of Efp mRNA to $43.5 \%$ was still observed after $72 \mathrm{~h}$ (Fig. 3B), meanwhile, the protein expression was also repressed. Whereas the mock control siRNA did not have any significant effect (data were not shown).

Effect of E2 on Ishikawa cell growth after Efp siRNA. Six hours after transfection, the medium was replaced with fresh medium containing E2 $\left(10^{-8} \mathrm{M}\right)$. At day 6 , Efp siRNAtransfected cells showed a growth rate slower than the control

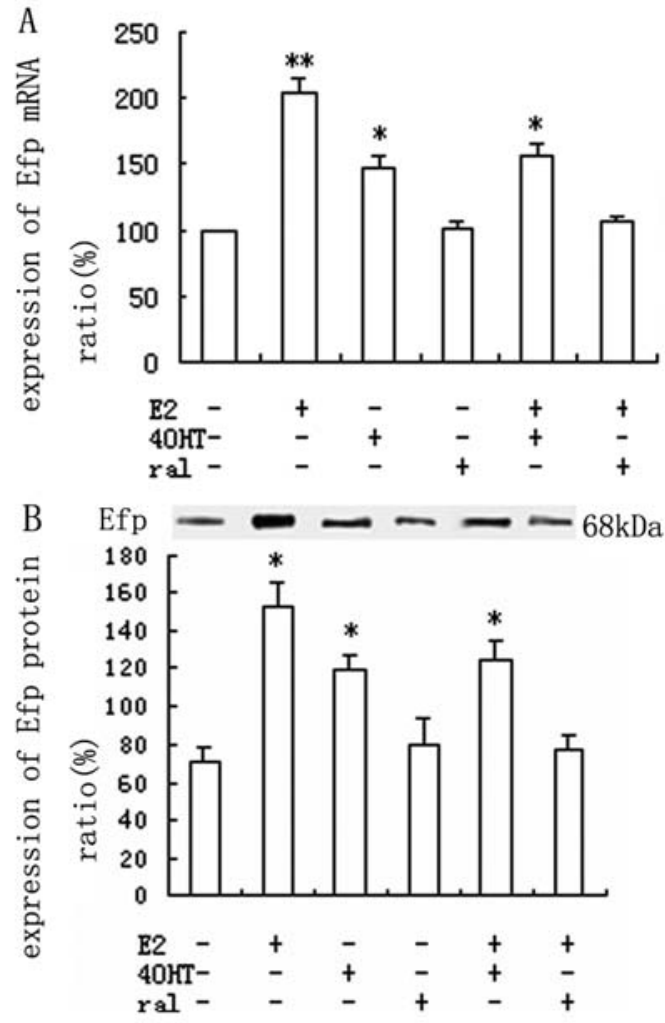

Figure 5. Induction of Efp by E2 and antiestrogens in Ishikawa cells. (A) Induction of Efp mRNA expression. Results were obtained from three separate experiments and expressed in percent of the control (here defined as $100 \%$ ) as mean \pm SE. (B) Induction of Efp protein expression. The semiquantitative measurements are expressed as mean $\pm \mathrm{SE}$ as percentage changes from an internal reference sample (the same for each gel). The asterisk indicates significant difference compared with the control $\left({ }^{* *} \mathrm{P}<0.01\right.$, $\left.{ }^{*} \mathrm{P}<0.05\right)$. Parent cells without treatment as control.

(Fig. 4). Mock siRNA was used as a control. No significant different growth rate of control transfected cells and parent cells was observed (data were not shown).

Induction of Efp by E2 and antiestrogens in Ishikawa cells. Ishikawa cells were treated with E2 $\left(10^{-8} \mathrm{M}\right), 40 \mathrm{HT}\left(10^{-7} \mathrm{M}\right)$, raloxifene $\left(10^{-7} \mathrm{M}\right)$ and ethanol (control). Three, 6, 12, 24 and $48 \mathrm{~h}$ later, cells were collected to measure the level of Efp mRNA and protein by QRT-PCR and Western blotting. The level of Efp mRNA and protein was increased significantly at $24 \mathrm{~h}$ after treatment by E2 $\left(10^{-8} \mathrm{M}\right), 40 \mathrm{HT}$ $\left(10^{-7} \mathrm{M}\right)$ and E2 $\left(10^{-8} \mathrm{M}\right)$ combination with $40 \mathrm{HT}\left(10^{-7} \mathrm{M}\right)$, that was not increased significantly before $12 \mathrm{~h}$, and was still increased at $48 \mathrm{~h}$ (data were not shown). Raloxifene $\left(10^{-7} \mathrm{M}\right)$ alone had no effect. When tamoxifen and raloxifene were combined with E2 $\left(10^{-8} \mathrm{M}\right)$, the induction of Efp by E2 was partly or completely inhibited (Fig. 5).

Induction of VEGF by E2 and antiestrogens in Ishikawa cells. Ishikawa cells were seeded and transfected as described in Materials and methods. Twenty-four hours later, the medium was replaced with fresh medium containing different compounds of indicated concentration. Parent cells without transfection were also treated with these compounds of the 


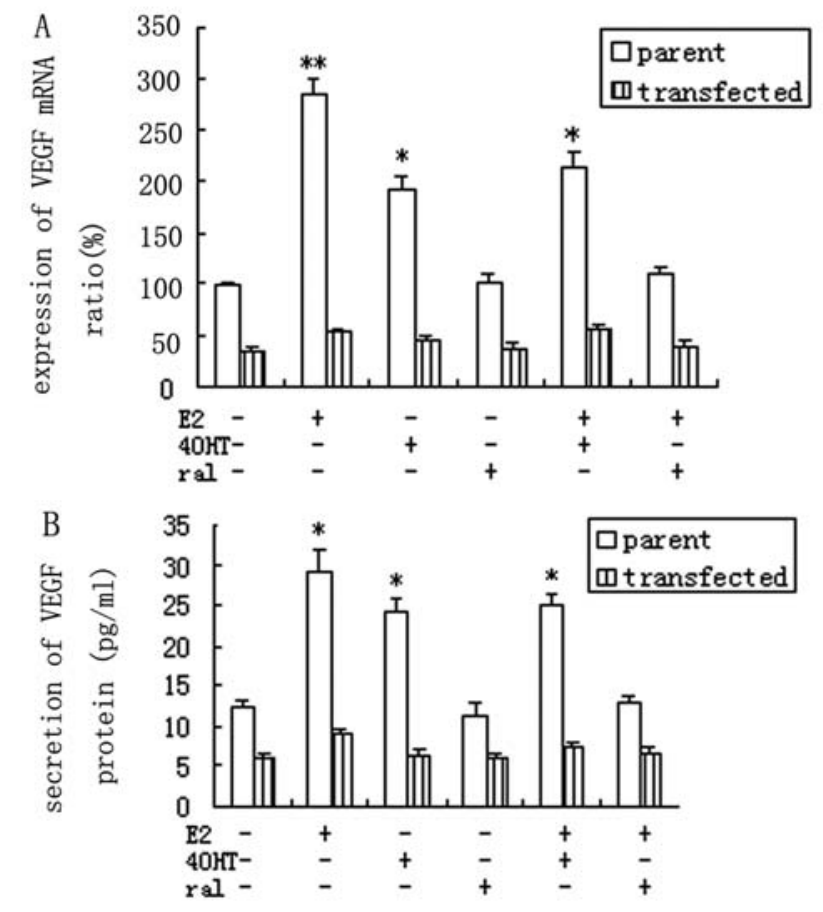

Figure 6. Induction of VEGF by E2 and antiestrogens in Ishikawa cells. (A) Induction of VEGF mRNA expression. (B) Induction of VEGF protein secretion. Results were obtained from three separate experiments and expressed as mean \pm SE. The asterisk indicates significant difference compared with the control. Parent cells without treatment as control $\left({ }^{* *} \mathrm{P}<0.001,{ }^{*} \mathrm{P}<0.05\right)$

same concentration. Cells and medium were collected after $3,6,12,24$ and $48 \mathrm{~h}$ to measure the VEGF mRNA and protein levels by QRT-PCR and ELISA. The expression of VEGF mRNA and protein secretion were increased in parent Ishikawa cells at $24 \mathrm{~h}$ after treatment by E2 $\left(10^{-8} \mathrm{M}\right)$, 40HT $\left(10^{-7} \mathrm{M}\right)$ and E2 $\left(10^{-8} \mathrm{M}\right)$ combination with $40 \mathrm{HT}$ $\left(10^{-7} \mathrm{M}\right)$, that was not increased significantly before $12 \mathrm{~h}$, and was still increased at $48 \mathrm{~h}$ (data were not shown). Raloxifene $\left(10^{-7} \mathrm{M}\right)$ alone had no effect, when it was combined with E2 $\left(10^{-8} \mathrm{M}\right)$, the induction of VEGF was almost completely inhibited, and tamoxifen partly inhibited the induction of VEGF by E2. Under all conditions tested, Efp siRNA-transfected cells showed a lower induction level than the parent cells (Fig. 6).

\section{Discussion}

Endometrial and breast cancers are important hormonedependent tumors that develop in women. The major risk factor for the two cancers is associated with lifetime exposure to estrogen (14). Estrogen is a major cause of tumorigenesis of the endometrium. The stimulatory effect of estrogen on cell proliferation may be regulated by up-regulation of Cyclin $\mathrm{D}_{1}$ and $\mathrm{A}$, and down-regulation of P53, P21 and P27 (15), or several signaling responses, including insulin-like growth factor 1, MAPK/ER/MDM2, PI3K/Akt and Pak (16- $^{-}$ 19), however, the mechanism is still uncertain.

Tamoxifen is the primary hormonal therapy for breast cancer and is also used as a breast cancer chemopreventative agent. A major problem with tamoxifen therapy is undesirable endometrial proliferation. Raloxifene has not been shown to have estrogenic effects on endometria in postmenopausal patients (20). However, Micheal et al found that raloxifene did not inhibit the growth of endometrial cancer cells in vitro, high concentrations even promoted cell growth (21). To evaluate the effects of estradiol and antiestrogens on the growth of Ishikawa cells, we performed growth experiments. Our experiments showed that E2 and 4OHT increased the growth rate of the cells, however raloxifene did not. This was consistent with previous observations that tamoxifen is an agonist of estrogen on Ishikawa endometrial cancer cells, and raloxifene acts as an antagonist (22-23). Surprisingly, when 4 OHT was combined with E2, the effect of stimulation by E2 was partly reduced, so tamoxifen also acts as an antagonist of estrogen. We did not find stimulation of the Ishikawa cell growth with the raloxifene treatment. The reason for this discrepancy may be related to the concentration of raloxifene, i.e., high concentrations might promote cell growth, lower concentrations (therapy concentration) may not.

E2 and tamoxifen are typical ligands for ER $\alpha$ that exhibit agonist and tissue-specific agonist-antagonist activities. There is evidence that 4OHT and other SERMs induce unique ER conformations that influence interactions with nuclear proteins and thereby modulate gene expression $(24,25)$. However, despite these conformational-induced changes in ER, tamoxifen is a potent ER agonist in certain cell lines for activation of ER $\alpha-\mathrm{Sp} 1$ and ERß-AP1 regulated genes or gene promoter constructs (26-29). Therefore, tamoxifen acted as estrogen agonist-antagonist in Ishikawa cells in vitro in this study.

Efp was first isolated from HeLa cells and found to be inducible when cells were treated with estrogen (30). Efp belongs to family of nuclear proteins, that contains a Ring finger motif, which has been implicated in transcriptional regulation, DNA repair and site-specific recombination. Efp expression in cancer has been studied predominantly in breast cancer. Efp was significantly correlated with poor prognosis of breast cancer patients, and it considered to be a new potential biomarker for breast cancer (31). Efp mRNA was detected in MCF-7 human breast carcinoma cells, and was induced by estrogen treatment, suggesting that Efp can mediate estrogen actions such as cell growth and is a primary responsive gene in breast cancer (32). Whereas, there are few studies on Efp in endometrial cancer. We found that treatment of E2 after $24 \mathrm{~h}$ resulted in about two-fold induction of Efp mRNA expression in Ishikawa endometrial carcinoma cells, 40HT also induced the Efp mRNA expression. Efp siRNA transfected Ishikawa cells showed a significantly slower growth rate than the control cells with treatment of E2. These results indicated that Efp was essential for cell growth induced by estrogen in Ishikawa cells and it could amplify the actions of estrogen.

VEGF is one of the most potent angiogenic factors favoring the development of new blood vessels and, therefore, contribute to the progression of tumors that depend on neovascularization (33). The regulation of VEGF expression by human tumor cells has been considered to be a key factor in human tumorigenic and metastatic potential $(34,35)$. 
Estradiol has been reported to increase VEGF gene transcription and protein secretion (36), and Lam et al found that raloxifene therapy in postmenopausal women was associated with a significant reduction in serum VEGF concentration (37). We investigated the effects of E2 and antiestrogens on the regulation of VEGF mRNA and protein secretion in Ishikawa cells that we confirmed expressing Efp and VEGF mRNA. We observed that the VEGF mRNA and protein secretion increased when treated with E2 and 4OHT, raloxifene did not regulate the level of VEGF mRNA and protein. This was consistent with Mueller et al (38) and Dardes et al (36). When the Efp gene was suppressed by siRNA transfection, the induction of VEGF mRNA and protein secretion by E2 and 4OHT decreased subsequently. These results indicated that the Efp transduction pathway was necessary to VEGF induction and cell growth and VEGF was a target for Efp in endometrial cancer cells. Therefore, it can be hypothesized that the major signal transduction pathway for E2 inducing the VEGF expression and cell growth may be through Efp in Ishikawa cells.

In conclusion, this study suggests that estradiol and tamoxifen may regulate the growth of endometrial cancer in part by stimulating VEGF production through the effect of Efp and thus increasing the density of the microvasculature. The results also support the hypothesis that tamoxifen acts as an agonist-antagonist and raloxifene acts as an antagonist of estrogen in Ishikawa cells. This study demonstrate that Efp is essential for estradiol induced cell proliferation in Ishikawa cells and it could amplify the actions of estradiol. A further investigation, whether Efp expression in tamoxifen-induced endometrial cancer biopsies correlates with VEGF expression, vascular density and prognosis, is now in progress.

\section{References}

1. Creasman WT, Odicino F, Maisonneuve P, Beller U, Benedet JL, Heintz AP, Ngan HY, Sideri M and Pecorelli S: Carcinoma of the corpus uteri. J Epidemiol Biostat 6: 47-86, 2001.

2. Fisher B, Costantino JP, Redmond CK, Fisher ER, Wickerham DL and Cronin WM: Endometrial cancer in tamoxifen-treated breast cancer patients: findings from the National Surgical Adjuvant Breast and Bowel Project (NSABP) B-14. J Natl Cancer Inst 86: 527-537, 1994.

3. Grady D, Ettinger B, Moscarelli E, Plouffe L Jr, Sarkar S, Ciaccia A and Cummings S: Safety and adverse effects associated with raloxifene: multiple outcomes of raloxifene evaluation. Obstet Gynecol 104: 837-844, 2004.

4. Dutertre M and Smith CL: Molecular mechanisms of selective estrogen receptor modulator (SERM) action. J Pharmacol Exp Ther 295: 431-437, 2000.

5. Orimo A, Inoue S, Ikeda K, Noji S and Muramatsu M: Molecular cloning, structure, and expression of mouse estrogen-responsive finger protein Efp. J Biol Chem 270: 24406-24413, 1995.

6. Inoue S, Urano T, Ogawa S, Saito T, Orimo K, Hosoi T, Ouchi Y and Muramatsu M: Molecular cloning of rat efp: expression and regulation in primary osteoblasts. Biochem Biophys Res Commun 261: 412-418, 1999.

7. Orimo A, Inoue S, Minowa O, Tominaga N, Tomioka $Y$, Sato M, Kuno J, Hiroi H, Shimizu Y, Suzuki M, Noda T, and Muramatsu M: Underdeveloped uterus and reduced estrogen responsiveness in mice with disruption of the estrogen-responsive finger protein gene, which is a direct target of estrogen receptor. Proc Natl Acad Sci USA 96: 2027-2032, 1999.

8. Chao JI, Kuo PC and Hsu TS: Down-regulation of survivin in nitric oxide-induced cell growth inhibition and apoptosis of the human lung carcinoma cells. J Biol Chem 279: 20267-20276, 2004.
9. Chen Z, Yuhanna IS, Galcheva-Gargova Z, Karas RH, Mendelsohn ME and Shaul PW: Estrogen receptor alpha mediates the nongenomic activation of endothelial nitric oxide synthase by estrogen. J Clin Invest 103: 401-406, 1999.

10. Seki N, Kodama J, Hongo A, Miyagi Y, Yoshinouchi M and Kudo T: Vascular endothelial growth factor and platelet-derived endothelial cell growth factor expression are implicated in the angiogenesis of endometrial cancer. Eur J Cancer 36: 68-73, 2000.

11. Kook HS, Hyun SL, Bongnam J, Hyun MK, Jung HC, Sung JP, Il HC, Hern KL and Suhn YI: Estrogen enhances angiogenesis through a pathway involving platelet-activating factor-mediated nuclear factor-кB activation. Cancer Res 64: 6482-6488, 2004.

12. Hervé MA, Meduri G, Petit FG, Domet TS, Lazennec G, Mourah S and Perrot-Applanat M: Regulation of the vascular endothelial growth factor (VEGF) receptor Flk-1/KDR by estradiol through VEGF in uterus. J Endocrinol 188: 91-99, 2006.

13. Nishida M, Kasahara K, Kaneko M, Iwasaki H and Hayashi K: Establishment of a new human endometrial adenocarcinoma cell line, Ishikawa cells, containing estrogen and progesterone receptors. Nippon Sanka Fujinka Gakkai Zasshi 37: 1103-1111, 1985.

14. Mahavni V and Sood AK: Hormone replacement therapy and cancer risk. Curr Opin Oncol 13: 384-389, 2001.

15. Jun W, Yuko K, Norihisa S, Isao O and Hiroyuka K: Stimulatory effect of estrogen on the growth of endometrial cancer cells is regulated by cell-cycle regulators. J Steroid Biochem Mol Biol 107: 163-171, 2007.

16. Zhu L and Pollard JW: Estradiol-17beta regulates mouse uterine epithelial cell proliferation through insulin-like growth factor 1 signaling. Proc Natl Acad Sci USA 104: 15847-15851, 2007.

17. Suga S, Kato K, Ohgami T, Yamayoshi A, Adachi S, Asanoma K, Yamaguchi S, Arima T, Kinoshita K and Wake N: An inhibitory effect on cell proliferation by blockage of the MAPK/estrogen receptor/MDM2 signal pathway in gynecologic cancer. Gynecol Oncol 105: 341-350, 2007.

18. Guo RX, Wei LH, Tu Z, Sun PM, Wang JL, Zhao D, Li XP and Tang JM: 17 beta-estradiol activates PI3K/Akt signaling pathway by estrogen receptor (ER)-dependent and ER-independent mechanisms in endometrial cancer cells. J Steroid Biochem Mol Biol 99: 9-18, 2006.

19. Mazumdar A and Kumar R: Estrogen regulation of Pak1 and FKHR pathways in breast cancer cells. FEBS Lett 535: 6-10, 2003.

20. Cano A and Hermenegildo C: The endometrial effects of SERMs. Hum Reprod Update 6: 244-254, 2000.

21. Hibner M, Magrina JF, Lefler SR, Cornella JL, Pizarro AR and Loftus JC: Effects of raloxifene hydrochloride on endometrial cancer cells in vitro. Gynecol Oncol 93: 642-646, 2004.

22. Sakamoto T, Eguchi H, Omoto Y, Ayabe T, Mori H and Hayashi S: Estrogen receptor-mediated effects of tamoxifen on human endometrial cancer cells. Mol Cell Endocrinol 192: 93-104, 2002.

23. Leblanc K, Sexton E, Parent S, Bélanger G, Déry MC, Boucher V and Asselin E: Effects of 4-hydroxytamoxifen, raloxifene and ICI182 780 on survival of uterine cancer cell lines in the presence and absence of exogenous estrogens. Int J Oncol 30: 477-487, 2007.

24. Norris JD, Paige LA, Christensen DJ, Chang CY, Huacani MR, Fan D, Hamilton PT, Fowlkes DM and McDonnell DP: Peptide antagonists of the human estrogen receptor. Science 285: 744-746, 1999.

25. Paige LA, Christensen DJ, Gron H, Norris JD, Gottlin EB, Padilla KM, Chang CY, Ballas LM, Hamilton PT, McDonnell DP and Fowlkes DM: Estrogen receptor (ER) modulators each induce distinct conformational changes in ER alpha and ER beta. Proc Natl Acad Sci USA 96: 3999-4004, 1999.

26. Emely CR and Stephen S: 17ß-Estradiol- and 4-hydroxytamoxifen-induced transactivation in breast, endometrial and liver cancer cells is dependent on ER-subtype, cell and promoter context. J Steroid Biochem Mol Biol 84: 23-31, 2003.

27. Jones PS, Parrott E and White IN: Activation of transcription by estrogen receptor alpha and beta is cell type- and promoterdependent. J Biol Chem 274: 32008-32014, 1999.

28. Barkhem T, Carlsson B, Nilsson Y, Enmark E, Gustafsson J and Nilsson S: Differential response of estrogen receptor alpha and estrogen receptor beta to partial estrogen agonists/antagonists. Mol Pharmacol 54: 105-112, 1998. 
29. Paech K, Webb P, Kuiper GG, Nilsson S, Gustafsson J, Kushner PJ and Scanlan TS: Differential ligand activation of estrogen receptors ERalpha and ERbeta at AP1 sites. Science 277: 1508-1510, 1997.

30. Inoue S, Orimo A, Hosoi T, Kondo S, Toyoshima H, Kondo T, Ikegami A, Ouchi Y, Orimo H and Muramatsu M: Genomic binding-site cloning reveals an estrogen-responsive gene that encodes a RING finger protein. Proc Nat Acad Sci USA 90: 11117-11121, 1993

31. Suzuki T, Urano T, Tsukui T, Horie-Inoue K, Moriya T, Ishida T, Muramatsu M, Ouchi Y, Sasano H and Inoue S: Estrogenresponsive finger protein as a new potential biomarker for breast cancer. Clin Cancer Res 11: 6148-6154, 2005.

32. Ikeda K, Orimo A, Higashi Y, Muramatsu M and Inoue S: Efp as a primary estrogen-responsive gene in human breast cancer. FEBS 472: 9-13, 2000.

33. Bermont L, Lamielle-Musard F, Chezy E, Weisz A and Adessi GL: 17beta-estradiol inhibits forskolin-induced vascular endothelial growth factor promoter in MCF-7 breast adenocarcinoma cells. J Steroid Biochem Mol Biol 78: 343-349, 2001 .
34. Folkman J and Shing Y: Angiogenesis. J Biol Chem 267: 10931-10934, 1992.

35. Plate KH, Breier G, Weich HA and Risau W: Vascular endothelial growth factor is a potential tumor angiogenesis factor in human gliomas in vivo. Nature 359: 845-848, 1992.

36. Dardes RC, Schafer JM, Pearce ST, Osipo C, Chen B and Jordan VC: Regulation of estrogen target genes and growth by selective estrogen-receptor modulators in endometrial cancer cells. Gynecol Oncol 85: 498-506, 2002.

37. Lam PM, Yim SF, Briton-Jones C, Chung TK and Haines C: Raloxifene therapy in postmenopausal women is associated with a significant reduction in the concentration of serum vascular endothelial growth factor. Fertil Steril 81: 393-397, 2004.

38. Mueller MD, Pritts EA, Zaloudek CJ, Dreher E and Taylor RN: Regulation of vascular endothelial growth factor by tamoxifen in vitro and in vivo. Gynecol Obstet Invest 55: 119-124, 2003. 